\title{
Moral (or ethical) education in Slovakia and its theoretical basis
}

\author{
Vasil Gluchman
}

\begin{abstract}
With regard to existing concept of the moral education (ethics) in Slovakia, the questions of ethics and morals are only one of the partial sections. The dominant role is played by psychology based on Roberto Olivar's concept with emphasis on pro-socialization and on Erickson's concept of the psychosocial development. From the philosophy basis point of view, only Aristotle, even in reduced form and Spranger's concept of the life forms are mentioned. Philosophy and ethics are only complements to more psychologically based educational program which is resulting from the problematic division of a social and moral experience into egoistic and prosocial. Egoism is presented in a distorted form and is characterized as the cause of all moral evil. However, there are several different types of understanding of the term egoism in philosophy and ethics as for example psychological and ethical egoism, or self-interest. Ethical egoism or self-interest cannot be identified with selfishness. The main aim of moral education should not be only to form the desired children and youth moral orientation but on the other hand, to form morally self-confident individuals who are able to solve the moral problems, to help the others to solve them as well and to be able to bear moral responsibility for their own deeds.
\end{abstract}

Keywords: moral education, ethical education, pro-social behaviour, Slovakia, Olivar, Spranger

\section{Introduction}

In Slovakia after 1989, the Ministry of education has endeavoured to put new values into the minds of the young generation that could replace the values of the socialist morals and concept of the socialist moral education. The former were focused on raising the mature citizen of the socialist society who would prefer loyalty to the working class ideals and to the communist classless society. As the result of such endeavour, from 1990 there have been several phases of the implementation of the moral education named ethical education ${ }^{1}$ at elementary and secondary schools. During the first phase (1990-1993), it was optional implementation of the subject 'ethical education' at the second grade of the elementary schools and at the first two years of the secondary schools. During the second phase (19932004), the subject 'ethical education' was introduced as the obligatory subject for the second grade of the elementary schools and the first two years of the secondary schools. During the third phase (2004-2005), ethical education was introduced as the obligatory subject also at the first grade of elementary schools. The origin of the ethical education concept and the implementation of this subject into the elementary and secondary schools curricula was in fact only a supplement to the introduction of a religious education into the school education system in Slovakia. ${ }^{2}$ Despite the fact that Ladislav Lencz presented the opinion that the ethical education implementation was accepted with understanding and the support of the professionals in Slovakia, Dušan Sukuba, a member of the Ministry of education professional

\footnotetext{
${ }^{1}$ The core of the ethical education concept was publicly by Ladislav Lencz (the concept author) and by one of the advisers, Brian Wakeman (Lencz, 1994, pp. 443-451; Wakeman, 1994, pp. 439-442).

${ }^{2}$ Ethical education was implemented as the additional compulsory subject (along with religious education) into the Slovak educational system always when the Minister of education was affiliated with the Christian Democratic Union.
} 
committee for the preparation of the ethical education model, wrote that the committee did not work systematically and the ministry management did prefer the opinions and standpoints of Ladislav Lencz that led to the implementation of the model based on education toward prosociality (Sukuba, 1999, pp. 274-275).

Ladislav Lencz claimed that the aim of the ethical education project was to restore the importance of the family and non formal groups in moral and human development within the Slovak society which was devastated by oppression and resembled a desert (Lencz, 1994, p. 449). However, Brian Wakeman articulated the background of the whole ethical education concept in Slovakia more clearly. He stated that he participated in preparations and implementation of the concept based on the impulse of the Christian Action Research and Education organisation, which strove for the implementation of Judaic-Christian values within the cultural heritage of Eastern European countries. In his opinion: "There was a warm response to suggestions about how certain major Christian values might inform the teaching of ethics in a culturally acceptable manner" (Wakeman, 1994, p. 439). As the consequence, it questions the sincere intention of the committee and the concept authors to create prerequisites for really ideologically objective moral education of children and youth whose parents do not belong to any religion. ${ }^{4}$

Another paradox arising from the Ministry's intention to ideologically influence the ethical education teaching is the fact that in 2004 in Slovakia, there were 41\% of the professional ethical education teachers who graduated from theological faculties, completing 'religious education - ethical education' double major teaching training courses (Beňo, 2004, p. 4). Theological faculties were preparing teachers for ethical education in Slovakia that should be ideologically neutral. There are doubts that in many cases the ideological neutrality of the teacher and the teaching process of ethical education in Slovakia were preserved.

\section{The content of the ethical education project in Slovakia}

The authors of this concept, in their attempt to repudiate the moral education in Slovakia before 1989, obscured the real content of their concept and they used the name that lacks professional foundation, i.e. ethical education. This name does not have equivalent terms in other languages since in an English speaking environment it is moral education and in German on Moralische Erzühung. ${ }^{5}$ The confusion of the terms ethics, ethical with the terms morality, moral of even virtuousness leak out into the everyday language of mass media, politics and common people. This could probably be the source of the name ethical education for the moral education in the Slovak educational system after 1989. Due to the fact that ethics (especially normative ethics) is considered to be a theoretical discipline dealing with morality and morals (Darwall, 1998; Gluchman, 2003; 2009, pp. 61-70; 2010, pp. 271-285; Kagan, 1998), it is evident that the term ethical education implies philosophical study of morals or education in the field of ethics rather than moral education. However, many articles have been published on the topic of ethical education (Bilasová, 2015, pp. 5-12; Kalajtzidis, 2015, pp. 13-20; Kaliský, 2009; Kaliský \& Kaliská, 2009, pp. 106-109; Klembarová, 2015, pp. 31-39; Lešková Blahová, 2015, pp. 41-49; Podmanický, 2013, pp. 233-242; Vargová, 2013, pp. 276-280).

\footnotetext{
${ }^{3}$ Wakeman also writes that 'several members of the team were committed Christians'; however, despite this fact, the whole concept is secular in his opinion (Wakeman, 1994, p. 441).

${ }^{4}$ For 2001 Census in Slovakia, there were 697308 (12,96\%) registered inhabitants without religious confession and another 160598 inhabitants did not state it (2,99\%) (Beňo, 2004, p. 4). In 2011 there were 725362 unbelievers (13,44\%) and 571437 people (10,58\%) did not express their worldview (Sčítanie obyvatel'ov, 2011).

${ }^{5}$ In English scholar works, the term ethical education is used for the ethical education in different professions, e.g. in medicine, business, accounting etc., that is not the moral education of the members of those professions (Asai et all., 1997, pp. 100-104; Jordan, 1992, pp. 17-21; Preece, 2002, pp. 21-33; Stephan, 2003, pp. 31-40, etc.).
} 
Despite the name of the whole concept is ethical education, in fact the concept consists of psychology of behaviour emphasising the education to pro-socialization. Basically, it is not an ethically and philosophically based concept that is why we can not find there the question "Why to be moral?" Consequently we cannot find sufficient ethical and philosophical explanation as to why this concept of education to pro-sociality, and not any other, was used as the basis for the ethical education project in Slovakia. The core of the whole concept is the theory of the Spanish psychologist Robert Roche Olivar (1992) emphasising only education to pro-socialization or basically only the theory of behaviour, which, under some circumstances, could be suitable for the elementary school students. ${ }^{6}$ The serious imperfection of the theory is the fact that the concept is reduced to repetition of the same thing at higher level at the level of the secondary school. The role of the moral education should be predominantly the reflection of the values of society, family and other social communities and forming the own values of children and young people. To attain this goal, the interdisciplinary approach, i.e. the knowledge of moral psychology, must be implemented. However, psychology cannot become the aim itself; it is only an instrument leading to a reflection of values.

Lencz, in Olivar's concept of pro-social education, has defined ten basic factors forming the prosocial behaviour of students, using them as the bases for ethical education: communication, self-esteem, and positive evaluation of others, creativity, ability to express one's feelings, empathy, assertiveness, pro-social models, pro-social behaviour and a comprehensive pro-socialness in public life. Five further factors are related to the behaviour of educators (both teachers and parents), and these generate principles of teacher-student interaction. They include unconditional acceptance of the student, attribution of pro-sociality and willingness to co-operate, positive discipline, encouragement to pro-social behaviour and careful use of reward and punishment (Lencz, 1994, p. 445).

Generally, it can be stated that Olivar's concept does not presuppose ethics, it even avoids it. The questions of morality are included only latently. He solves only questions of exercising the pro-sociality without deeper connection with existing state of morality. Elements needed to solve the interpersonal problems (Olivar, 1992, p. 69) or the theory of syneactics (Olivar, 1992, p. 75), lacking the attributes of the moral education and emphasising predominantly psychological aspects of the problems, can be seen as examples. The moral or ethical education should lead children to be aware of the moral aspect of the problems which is not identical with psychological one. Similarly, the model of the pro-social personality, presented in this concept, is the psychological portrait of a successful man that is unattainable for an average person (Olivar, 1992, pp. 135-136). The moral dimension is only the marginal issue that belongs to the image of a successful person.

A very strong, even dominant moment of the concept is the altruistic one, which is clearly expressed by one type of pro-social behaviour. "Contrary to other types of behaviour (...)that are common among friends and that satisfy the needs of the author of the activity in a social context, pro-social behaviour presupposes the cutting off of one's own personal needs and serving the needs of others" (Olivar, 1992, p. 149). It is connected with understanding of cooperation, which "... often means that we have to help each other under the condition of reciprocal exchange. The reciprocal exchange, however, has a character of agreement which

\footnotetext{
${ }^{6}$ As the author of the concept, Ladislav Lencz himself states the Olivar's theory is exercised only in some parts of Spain, Portugal and Latin American countries (Lencz, 1994, pp. 444-445). Based on that fact, the question arises why this not well-accepted theory from the culturally different environment has become the core for its application in Slovakia. The fact that there are nearly no citations of Roche Olivar ideas in European and the world databases of professional journals (which is one of the most important criteria for acceptance of the author) can be considered as the evidence as well. Some critics of the concept claim that Olivar's theory is reflected only in countries with strong position of the Catholic Church (Beňo, 2004, p. 4; Škoda, 2004, p. 4).
} 
annoys pro-sociality" (Olivar, 1992, p. 156). Lencz in particular emphasises altruistic aspects of pro-sociality that play the dominant role also in the concept of the ethical education. ${ }^{7}$

The existing model of ethical education in Slovakia, especially in connection with the secondary school students shows imperfection since it is not dealing with the content of ethics, morality, values, etc. This model is reduced to forming the behaviour of children and young people (in a spirit of altruism and pro-sociality) and to etiquette without even trying to explain social, historical and cultural contexts that form and influence moral values and norms of society, as well as individuals. This concept coming out from the psychology of behaviour does not even deal with such moral problems as justice, responsibility, tolerance, etc.

Regardless of the above mentioned, Lencz says "without this basis [prosocial education], it is not possible to talk meaningfully about the individual problems of ethics" (Lencz, 1992c, p. 10). In fact, education to pro-sociality, presented as the basis of the ethical education in Slovakia is only a laboratory based experiment implemented in reality, which does not count with the external conditions. Consequently, it could even lead to frustration of children and young people undergoing this experiment later, in their real life they would find out that the conditions and aims formulated by the experiment (in education to pro-sociality) are totally different from life, i.e. there are obstacles for implementation of the learnt model of behaviour. The concept of the ethical education in Slovakia, based on education to prosociality is utopian and maximized, since it does not take 'is' into consideration but it formulates utopian and maximized 'ought'. The serious difficulty for implementing the ethical education in Slovakia is that any other concept of the moral education could be the atmosphere in society. Unless the state and society would create the atmosphere to inspire people to act morally (starting from the top representatives of the state), to understand that it is worth it to be moral since evil and immorality are harmful and would be punished, until that time the expectation and hopes for success of any concept would be minimal. "In order that man may become virtuous, it is absolutely requisite that he should have an interest that he should find advantages in practising virtue. For this end, it is necessary that education should implant in him reasonable ideas; that public opinion should lean towards virtue, as the most desirable good; that example should point it out as the object most worthy esteem; that government should faithfully recompense, should regularly reward it; that honour should always accompany its practice; that vice should constantly be despised; that crime should invariably be punished" (Holbach, 2004, p. 109).

\section{Ethics and morality in the concept of the ethical education in Slovakia}

In the existing concept of the ethical education, ethical and moral problems are only partial segments similar to religion or economy. It does not play a fundamental and decisive role, as it has been claimed (Lencz, 1997, p. 476). To fulfil such an important role that ethics should have in forming moral education, it is not enough to mention it among other twelve components and to provide one or two not very clearly chosen authors (Lencz, 1992a). The core of the whole concept of moral education should be all the best experience from the existing moral development of humanity that are included in the heritage of the historical development of the ethical thinking in the world. Instead of philosophy and ethics with usage of knowledge from psychology and pedagogy being the basis for moral education concept, it is psychology, applied in different spheres of life that is the basis of the concept. The example is the fact that the base and majority of the ethical education project is created by psychologically oriented topics, followed by ethics, questions of religion and finally the topic dealing with economic values. The similar character could be found in definitions of virtues, which are rather psychological and not philosophical (Lencz et all., 1994). The rules of the

\footnotetext{
${ }^{7}$ See examples of activities 12.3 and 12.4 for chapter Religion (Lencz et all., 1994).
} 
pro-social behaviour are description of desired psychological states and not the description of the moral aims that the man should aspire for (Lencz, 1994, pp. 5-6; Lencz \& Ivanová, 1995, pp. 12-13). Philosophy and ethics within this concept of ethical education are only supplements to the psychologically based educational program coming out of problematic division of social and moral practise (especially human being behaviour division) into egoistic and pro-social. The whole concept is based on "either we would close ourselves into our egoism or we would open our hearts and our doors for others. In other words, either we would be in pro-social position or we would remain egoists" (Lencz et all., 1994, p. 15). I am not convinced that this schematic vision and evaluation of social and moral reality is sufficient base for solving the complex moral problems of society and individual in our century.

The dominant role within the project is played by psychology of behaviour based on Erikson's concept of psychosocial development (along with Olivar's theory). Erikson's concept is in fact the concept of psychosocial development which is related to moral judging of individual only partially. Similarly, it participates in influencing the moral action of a person only partially (Džuka, 1998, pp. 54-57). Regardless, it contains certain moral aspects it is not possible to build the whole concept of the moral education on those aspects, since the polar categories, used by Erikson in his theory, cannot be used to describe the problems of morals and morality.

Among the works from philosophy used as the basis for the concept, only Aristotle, even in reduced form, and Eduard Spranger (1882-1963) are mentioned. It is definitely insufficient number of sources to justify the moral education concept from philosophical point of view. Similarly, it is not adequately explained why those two philosophers are considered to be the theoretical starting points for the concept of the ethical education in Slovakia. Besides, Spranger's theory did not belong among the most important philosophical conception that should be implemented more than 100 years since its beginnings (Spranger, 1914/1928). In the current philosophical literature, Spranger is only briefly mentioned in encyclopaedias, and his work is not in the centre of present-day philosophical discussions. In modern psychology his concept is accepted mainly as a tool for testing and demonstration of types of personalities (Popplestone \& McPherson, 1988, pp. 343-344). Freud, Jung and Fromm, his contemporaries and one of the most important psychologists ever, almost did not comment the Spranger's work and his types of personality concept. The modern psychological research on personality is concentrating on totally different issues than Spranger's one. In connection with these facts, the question why Spranger's more or less psychological concept of the types of personality was used as the only philosophical base of the ethical education is apparent.

Another evidence of the poor theoretical embedment of the ethical education concept and its dominant psychological base is the fact that exclusively psychological works are enlisted among the theories of education (Lencz \& Krížová, 1993, pp. 11-40). Based on the above mentioned facts I hold an opinion that the existing concept of the ethical education in Slovakia is poorly backed up. The moral education, without this type of justification, is rather an ideological tool and not the concept which should fulfil the requirements and need of the century. The existing concept of the ethical education unilaterally emphases emotional side (psychologically based) rather then rational one and it doesn't create enough space for own moral cognition especially for older students. I do not want to question the importance and role of emotional aspects within the moral education; however, I am not convinced that it is a universal approach. The emotional side itself is not a sufficient base for answering everyday moral problems.

The concept of the ethical education in Slovakia does not allow for the fact that all individuals within the same age group are at different level of intellectual, psychological and moral development. It comes from the presumption that all people are the same and it works with them in the same way. Even though we would have trust in a man and his/her abilities, 
we have to admit that there are natural differences (which do not doubt the moral equivalence) and that we must accept different approach within the moral education. It would be more productive to use the potential of the Kohlberg's concept of moral development, which is elaborated in details and which concentrates on similarities and differences in the moral development of a person. This concept has deep philosophical roots (Kohlberg, 1981) and is well-developed in pedagogy as well (Peters, 1974). Naturally, it contains some imperfection and weak points, however experience from different countries shows that they can be mastered and eliminated. Lencz's statement that "in the works of Jean Piaget and Lawrence Kohlberg we see mainly confirmation of the pro-sociality project (and ethical education) correctness: autonomy or post-conventional phase of moral development is not conceivable without pro-sociality" (Lencz, 1995, p. 110) is in principle not accurate and as such is wrong. One of the important conclusions of Kohlberg research is that majority of adults reach only the level of conventional morality (Kohlberg, 1981, p. 46). Kohlberg characterises the postconventional phase of moral development through priority of laws and social agreement and also through universal ethical principles expressing respect for man (Kohlberg, 1981, pp. xxvii-xxviii). However, the base is formed by the value of justice and not pro-sociality. ${ }^{8}$

Within the scope of ethical education in Slovakia Lencz performs several examples of ideology, such as in connection with rejection of the term moral education. Another example of ideology of this concept was the activity 12.11 Christianity and Slovak history within the topic about religion where the whole contribution of Slovak Lutherans to preservation and development of the Slovak nation, especially till 1918 is totally ignored (Lencz et all., 1994, pp. 79-80). It is not adequate for cognition of the role and importance of religion in the life of the Slovak nation to bypass or suppress the asset of Štúr generation, Pavol O. Hviezdoslav or other representatives of the Slovak nation from the period after 1918 as the writers Martin Rázus, Emil Boleslav Lukáč and number of others from among the Slovak Lutherans (Gluchman, 1997; 2007). At the same time it is not a good example for upbringing to tolerance (religious tolerance including), which is the part of the ethical education concept.

\section{Egoism and pro-sociality}

In existing concept of the ethical education in Slovakia pro-sociality is emphasised in contrast to egoism but this term is filled with political and ideological content rather than philosophical. It should not happen in ethics or the moral education when we want to avoid the mistakes and imperfections from the past. Egoism is characterised as the reason of all moral evil that exists among people. In fact, it is only shoddy argumentation at the moralizing level that replaces the real objective analysis of the term content. The example of such argumentation is the statement that competitiveness supports egoism rather than pro-sociality. That is why, in Lencz opinion, it is advisable to emphasise cooperation rather than competitiveness (Lencz, 1992b, p. 19).

The term egoism does not need to be threatening or a kind of spectre through which the existence of moral evil in us and in the world could be easily explained. Even Thomas Aquinas claimed that the main aims of our human activity is God, the person himself and others (Aquinas, 1991, p. 255). He also added that responsibility for our own life is bigger than the one we should have for others. In his opinion when we would deal with our own issues, there is higher probability of a peace on the Earth (Aquinas, 1991, pp. 390-391). Also Kant distinguishes between duty to one's self and duty to others. For the first type, he claims that keeping the perfection of our substance and acting in accordance with the will of a person, expressing dignity of humanity in him, takes the first position (Kant, 1983, p. 80).

\footnotetext{
${ }^{8}$ When justifying concept of the ethical education, certain terms as contrast of egoism and pro-sociality (Spranger's type of personality concept) are reduced and conclusions of existence of pro-sociality are implemented in different concepts (Kohlberg's concept).
} 
Even earlier, Marcus Aurelius expressed the essence of human activity very clearly when he wrote: "The ambitious supposeth another man's act, praise and applause, to be his own happiness; the voluptuous his own sense and feeling; but he that is wise, it is his own action" (Marcus Aurelius, 2004, p. 62). Similar expressions could be fund in Epictetus who was another representative of the Roman stoicism (Epictetus, 2004, p. 102). ${ }^{9}$

Spinoza even put adequate knowledge of self as the prerequisite for reaching virtue, i.e. knowledge of a God and intellectual love for Him. As the result, a man and his knowledge of himself are the starting points for endeavouring for moral perfection and reaching the highest moral values. In his opinion, the fundamental condition or the base for reaching the perfection is preserving our existence and satisfying our needs that are connected with it. It is contained in Spinoza's second and the third rule of life (Spinoza, 1955, p. 7).

Erich Fromm who acknowledged Spinoza as one of his intellectual sources, made certain analogy in the Spinoza's vein: "Man has only one real interest and that is the full development of his potentialities, of himself as a human being. Just as one has to know another person and his real needs in order to love him, one has to know one's own self in order to understand what the interests of this self are and how they can be served" (Fromm, 1999, p. 134).

Talking about egoism it is necessary to say that philosophy and ethics distinguish different types of egoism. The most common is a division of egoism into ethical and psychological one (Rachels, 1993). The psychological egoism is an expression of what we normally know as selfishness, preferring own intentions and needs regardless of the intentions and needs of others. Ethical egoism, which has a number of other names in philosophy and ethics such as rational egoism or self-interest, concentrates on our endeavour to act for benefit of others expressing our desire for others to act on our own benefit. It means the reciprocity of action under the condition that we do not harm ourselves or the others. It is in fact the implementation of the Golden Rule of morality and on the other hand, a specific notion of the summum bonum for all participants. As such it can not deny the fundamental rules and legitimate concerns of others as could be comprehended from the vulgarized term egoism. Lencz's interpretation of egoism is totally different, obscuring its qualitative differentiation.

On the other hand, there is pro-sociality, representing certain input in favour of summum bonum with certain (not always clear) importance for acting person. It seems as giving preference to acting of good for the sake of good itself. It really resembles Kant's or Kierkegaard's view expressing rejection of empirical motives of activity. Based on this position, the only moral action is the one preferring moral action for the sake of morality as such. I do not question the role and importance of pro-sociality in our lives and in moral life of society. My aim is to point at the fact that orientation on pro-sociality does not cover the whole issue of morals, morality and moral education and that it does not give prerequisite for moral development of all powers and skills of the moral agent. It is more to make sure that we would not change one extreme in the moral education for another.

The results of comparative sociological and psychological research among Slovak students of secondary school and university and young people from other countries prove that generally accepted moral values related to the value of human life and dignity, peace and freedom, family happiness, health, love and friendship, religion and faith, good work and the importance of being needed have the significant position in the Slovak young people moral orientation. Similarly it is necessary to take into consideration the will of a young generation to help others and their endeavour to factor the need of others in their decisions. This is the starting point for possibility to develop the interpersonal relations in society, with emphases on value of a person and his/her interest in those relations. It should be used also for the elementary and secondary schools moral education (Gluchman, 1996).

\footnotetext{
${ }^{9}$ Lencz gives stoicism as one of the examples in the human history making connection to the ethical education concept and the idea of pro-sociality (Lencz, 1995, p. 109).
} 
However, the above mentioned researches shown that in some aspects the Slovak young people stay behind the young people from other countries. It is illustrated by acceptance of themselves as well as realistic image of the world. The same applies to self-appreciation or comparison of positive attitude to life and awareness of problems (Džuka, 1994; 1995; Džuka et all., 1993). It seems that upbringing to collectivism which dominated education in Slovakia before 1989 could cause fear that the attempts to assert oneself, to accomplish own interests would be labelled as egoism or selfishness.

\section{Conclusion}

Moral education should deal not only with forming the desired moral orientation but also it should form morally self-confident individuals able to solve their moral problems, help others with solving their problems and to bear moral responsibility for their actions. I presume that this is the aim of all who are directly or indirectly connected with the moral education of students in families, schools and all other levels of education. At the same time I have serious doubts that the project of ethical education implemented in Slovakia at the moment would accomplish this task completely.

\section{Acknowledgement}

This paper is a part of the research project - KEGA 005PU-4/2014 Nové výzvy pre učitel'a etickej výchovy v 21. storočí (New challenges for Ethics teacher in the $21^{\text {st }}$ century).

Vasil Gluchman is Professor of Philosophy and Ethics at the Institute of Ethics and Bioethics, University of Prešov (Slovakia). He is an author of Profesijná etika ako etika práce a etika vztahov [Professional Ethics as Work Ethic and Ethics of Relationships], Prešov: FF PU 2014; Etika a reflexia morálky [Ethics and Reflection of Morality], Prešov: FF PU 2008; Human Being and Morality in Ethics of Social Consequences, Lewiston, NY: Edwin Mellen 2003; Slovak Lutheran Social Ethics, Lewiston, NY: Edwin Mellen 1997; editor of Ethical Thinking on Past \& Present (ETPP 2013), Prešov: VPU 2014; Morality: Reasoning on Different Approaches, Amsterdam \& New York: Rodopi 2013, and Morality of the Past from the Present Perspective: Picture of Morality in Slovakia in the First Half of the Twentieth Century, Newcastle: Cambridge Scholars Publishing 2007.

\section{Corresponding author:}

Vasil Gluchman, Institute of Ethics and Bioethics, University of Prešov, 17. novembra 1, SK-08078 Prešov (Slovakia)

email: vasil.gluchman@unipo.sk

\section{References}

AQUINAS, ST T. (1991): Summa Theologiae. London: Methuen.

ASAI, A., KISHINO, M., FUKUI, T. \& MASANO, T. (1997): Postgraduate Education in Medical Ethics in Japan. In: Medical Education, 32(1), pp. 100-104.

BEŇO, M. (2004): Nealternatívna alternatíva [Non-alternative choice]. In: Učitel'ské noviny, 54(32), p. 4.

BILASOVÁ, V. (2015): Ethics and/as education. In: Ethics \& Bioethics (in Central Europe), 5(1-2), pp. 5-12.

COSTA, P. T. \& MCCRAE, R. R. (1992): The Five-Factor Model of Personality and its Relevance to Personality Disorders. In: Journal of Personal Disorders, 6, pp. 343-359.

DARWALL, S. (1998): Philosophical Ethics. Boulder: Westview Press. 
DŽUKA, J. (1995): Sebaaktualizácia a subjektívna pohoda u slovenskej a nemeckej mládeže [Self-actualization and subjective comfort of Slovak and German youth]. In: Československá psychologie, 39(1), pp. 28-39.

DŽUKA, J. (1994): Subjektívna pohoda u slovenskej a rakúskej mládeže [Subjective comfort of Slovak and Austrian youth]. In: Československá psychologie, 38(3), pp. 193-205.

DŽUKA, J. et all. (1993): Psychická pohoda u slovenskej a švajčiarskej mládeže [Mental comfort of Slovak and Swiss youth]. In: Psychológia a patopsychológia diet'at'a, 28(4), pp. 309-322.

EPICTETUS (2004): The Discourses. Whitefish: Kessinger.

FROMM, E. (1999): Man for Himself: An Enquiry into the Psychology of Ethics. London: Routledge.

GLUCHMAN, V. (2009): „Etická výchova“ a morálne myslenie (etika sociálnych dôsledkov ako východisko modelu mravnej výchovy) ["Ethical education" and moral thinking (ethics of social consequences as a model of moral education)]. In: ̌̆. Ligas (ed.): Mravná výchova $v$ školách na Slovensku a vzahraničí [Moral education at schools in Slovakia and foreign countries]. Banská Bystrica: PF UMB, pp. 61-70.

GLUCHMAN, V. (1996): Hodnoty a mravné hodnoty slovenských vysokoškolákov [Values and moral values of the Slovak university students]. In: Pedagogická revue, 48(5-6), pp. 237246.

GLUCHMAN, V. (2003): Human Being and Morality in Ethics of Social Consequences. Lewiston: Edwin Mellen Press.

GLUCHMAN, V., ed. (2007): Morality of the Past from the Present Perspective: Picture of Morality in Slovakia in the First Half of the Twentieth Century. Newcastle: Cambridge Scholar Publishing.

GLUCHMAN, V. (2010): Mravná výchova na Slovensku v súčasnosti a jej teoretické východiská [Moral education in contemporary Slovakia and its theoretical starting points]. In: W. Słomski (ed.): W strone szczescia [On a side of happiness]. Warszawa: Heliodor, pp. 271285.

GLUCHMAN, V. (2003): Slovak Lutheran Social Ethics. Lewiston: Edwin Mellen Press.

HOLBACH, P. H. T. (2004): The System of Nature, vol. 1. Whitefish: Kessinger.

JORDAN, T. (1992): Ethical Education after Fitzgerald: Return to a Golden Past or the end of Civilisation as we know it? In: Social Alternatives, 11(3), pp. 17-21.

KAGAN, S. (1998): Normative Ethics. Boulder: Westview Press.

KALAJTZIDIS, J. (2015): Value of responsibility in ethical (moral) education. In: Ethics \& Bioethics (in Central Europe), 5(1-2), pp. 13-20.

KALISKÝ, J. (2009): Etická výchova v nemecky hovoriacich krajinách [Ethical education in German speaking countries]. Banská Bystrica: PF UMB.

KALISKÝ, J. \& KALISKÁ, L. (2009): Aká je etická výchova na Slovensku [What is ethical education in Slovakia]? In: Š. Ligas (ed.): Mravná výchova v školách na Slovensku a $v$ zahranič [Moral education at schools in Slovakia and foreign countries]. Banská Bystrica: PF UMB, pp. 106-109.

KANT, I. (1983): The Metaphysical Principles of Virtue. Indianapolis \& Cambridge: Hackett. KLEMBAROVÁ, J. (2015): The school classroom as a prejudice-free zone. In: Ethics \& Bioethics (in Central Europe), 5(1-2), pp. 31-39.

KOHLBERG, L. (1981): Essays on Moral Development: The Philosophy of Moral Development: Moral Stages and the Idea of Justice, vol. 1. San Francisco: Harper \& Row.

KUDLAČOVÁ, B. (2009): História, súčasnost' a perspektívy predmetu etická výchova v SR

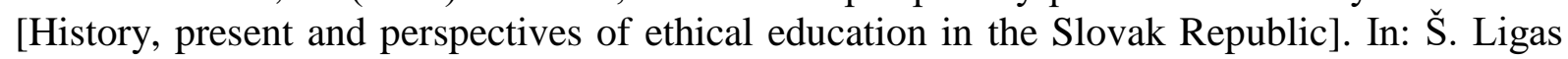
(ed.): Mravná výchova v školách na Slovensku a v zahraniči [Moral education at schools in Slovakia and foreign countries]. Banská Bystrica: PF UMB, pp. 133-140. 
LENCZ, L. (1992a): K teoretickým východiskám etickej výchovy [Theoretical starting points of ethical education]. In: V. Rosová \& G. Bianchi (eds.): Morálna a environmentálna výchova [Moral and environmental education]. Bratislava: Kabinet výskumu sociálnej a biologickej komunikácie SAV, pp. 15-28.

LENCZ, L. (1995) Koncepcia etickej výchovy [Concept of ethical education]. In: C. Diatka, Š. Pongó \& E. Berger (eds.): Uplatnenie objektivnych etických noriem $v$ školskom a mimoškolskom vzdelávani [The application of objective ethical standards in school and afterschool education]. Nitra: VŠPg, pp. 105-114.

LENCZ, L. (1994): Metódy etickej výchovy [Methods of ethical education]. Bratislava: Metodické centrum.

LENCZ, L. (1992b): Pedagogika etickej výchovy [Pedagogy of ethical education]. Bratislava: Metodické centrum.

LENCZ, L. (1997): Poznámky ku koncepcii učebného predmetu etická výchova [Notes to ethical education subject]. In: Pedagogická revue, 49(9-10), pp. 476-482.

LENCZ, L. (1994): The Slovak Ethical Education Project. In: Cambridge Journal of Education, 24(3), pp. 443-451.

LENCZ, L. (1992c): Úvod [Introduction]. In: R. R. Olivar: Etická výchova [Ethical education]. Bratislava: Orbis Pictus Istropolitana, pp. 5-10.

LENCZ, L. et all. (1994): Metodický materiál k predmetu etická výchova, II. čast' [Teaching material for ethical education, vol. II]. Bratislava: Metodické centrum.

LENCZ, L. \& IVANOVÁ, E. (1995): Metodický materiál k predmetu etická výchova, III. čast' [Teaching material for ethical education, vol. III]. Bratislava: Metodické centrum.

LENCZ, L. \& KRÍŽOVÁ, O. (1993): Metodický materiál $k$ predmetu etická výchova [Teaching material for ethical education]. Bratislava: Metodické centrum.

LEŠKOVÁ BLAHOVÁ, A. (2015): The relevance and role of environmental values in ethics education (in the context of environmental ethics). In: Ethics \& Bioethics (in Central Europe), 5(1-2), pp. 41-49.

MARCUS AURELIUS (2004): Meditations. Whitefish: Kessingers.

OLIVAR, R. R. (1992): Etická výchova [Ethical education]. Bratislava: Orbis Pictus Istropolitana.

PETERS, R. S. (1974): Psychology and Ethical Development. London: George Allen \& Unwin.

PODMANICKÝ. I. (2013): Etická výchova ako súčast’ školskej edukácie v polarizovanej spoločnosti [Ethical education as part of school education in a polarized society]. In: J. Kaliský (ed.): Dobro a zlo, alebo o morálke: Psychologické a filozofické aspekty morálky $v$ edukácii [Good and evil or about morality: Psychological and philosophical aspects of morality in education]. Banská Bystrica: PF UMB, pp. 233-242.

POPPLESTONE, J. A. \& MCPHERSON, M. W. (1988): Dictionary of Concepts in General Psychology. New York: Greenwood Press.

PREECE, J. (2002): Feminist Perspectives on the Learning of Citizenship and Governance. In: Compare, 32(1), pp. 21-33.

SČÍTANIE OBYVATELOV, DOMOV A BYTOV 2011. [Retrieved, 15 March 2016]. Available at: http://census2011.statistics.sk/tabulky.html.

RACHELS, J. (1993): The Elements of Moral Philosophy. New York: McGraw-Hill.

SPINOZA, B. B. (1955): On the improvement of human understanding. In: The Chief Works of Benedict de Spinoza, vol. 2. New York: Dover Publications, pp. 1-41.

SPRANGER, E. (1914/1928): Types of Men: The Psychology and Ethics of Personality, trans. by Paul John William Pigors. Halle: Max Niemeyer Verlag.

STEPHAN, K. D. (2003): How ethics was specialized away. In: Academic Questions, 16(4), pp. 31-40. 
SUKUBA, D. (1999): Psychológia prosociálnej výchovy na Slovensku ako učebný predmet etická výchova [Psychology of pro-social education as ethical education subject]. In: Pedagogická revue, 51(3), pp. 274-275.

ŠKODA R. (2004): Rád vysvetlím, kto sú humanisti [I want to explain, who are humanists]. In: Učitel'ské noviny, 54(44-45), p. 4.

VARGOVÁ, D. (2013): Výchova k prosociálnosti ako prostriedok, nie ciel' etickej výchovy [Education towards pro-socialization as an instrument not as the main aim of ethics education]. In: J. Kaliský (ed.): Dobro a zlo, alebo o morálke: Psychologické a filozofické aspekty morálky vedukácii [Good and evil or about morality: Psychological and philosophical aspects of morality in education]. Banská Bystrica: PF UMB, pp. 276-280.

WAKEMAN, B. (1994): The Slovak Ethical Education Project: A View from the UK. In: Cambridge Journal of Education, 24(3), pp. 439-442. 